\title{
Influence of fatty acid composition on the formation of polar glycerides and polar fatty acids in sunflower oils heated at frying temperatures
}

\author{
By N. Jorge1, L. Ap. Guaraldo Gonçalves² and M. C. Dobarganes' \\ 1 Instituto de la Grasa (CSIC). Avda. Padre García Tejero, 4. 41012 Sevilla. Spain. \\ 2Laboratorio de Oleos e Gorduras, Faculdade de Engenharia de Alimentos, Universidade Estadual \\ de Campinas-UNICAMP. CEP 13081-97 Campinas, S. P.
}

\section{RESUMEN}

Influencia de la composición de ácidos grasos en la formación de glicéridos polares y ácidos grasos polares en aceites de girasol calentados a temperaturas de fritura.

Aceites de girasol convencional y alto oleico así como una mezcla al $50 \%$ de ambos fueron calentados a diferentes temperaturas bajo condiciones controladas. Se cuantificaron los compuestos polares totales, los grupos principales de glicéridos, ácidos grasos polares totales, los grupos principales de ácidos grasos polares y la pérdida de ácidos grasos iniciales.

Los resultados más relevantes demostraron la primacía de la formación de compuestos de polimerización glicerídicos durante el calentamiento a altas temperaturas. Después de la transesterificación de las muestras, los ácidos diméricos constituyeron el grupo más significativo de compuestos obtenidos. Como era esperado, el ácido linoleico contribuyó preferentemente en la formación de los ácidos grasos polares, si bien la participación del ácido oleico fue muy importante a bajas concentraciones de ácido linoleico. Finalmente, se obtuvieron buenos resultados estadísticos para la regresión entre ácidos grasos polares y compuestos polares.

PALABRAS-CLAVE: Aceite de girasol calentado - Ácidos grasos polares (formación) - Composición de ácidos grasos (influencia) - Glicéridos polares (formación).

\section{SUMMARY}

Influence of fatty acid composition on the formation of polar glycerides and polar fatty acids in sunflower oils heated at frying temperatures.

Conventional and high oleic sunflower oils as well as $50 \%$ mixture of both of them were heated at different temperatures under well-controlled conditions. Total polar compounds, the main groups of polar glycerides, total polar fatty acids, the main groups of polar fatty acids and the loss of initial fatty acids were quantitated.

The most outstanding results demonstrated the primacy of the formation of glyceridic polymerization compounds during heating at high temperatures. After transesterification of the samples dimeric fatty acids was the most significant group of compounds obtained. As expected, linoleic acid was preferentially

Part of the Doctoral Thesis of Neuza Jorge to be submitted to Faculdade de Engenharia de Alimentos, Universidade de Campinas, Campinas, Brazil. involved in the formation of polar fatty acids, although the participation of oleic acid became very important at low concentration of linoleic acid. Finally, good statistical figures were obtained for the regression of polar fatty acids on polar compounds.

KEY-WORDS: Fatty acid composition (influence) - Polar fatty acids (formation) - Polar glycerides (formation) - Sunflower oil heated.

\section{INTRODUCTION}

Chemical evaluation of frying fats and oils has been considerably improved in the last two decades due to the emergence of new methodologies quantitating the new compounds formed during the frying process.

Determination of polar compounds stands out as the most used analytical method evaluating the total amount of polar glycerides formed by means of adsorption chromatography on silica (Waltking and Wessels, 1981). Additionally, high performance size exclusion chromatography (HPSEC) allows quantitation of polymeric glycerides, the most important group of new compounds formed at high temperature, in just 1520 minutes (Perrin et al., 1984; Wolf et al., 1992). Also, combination of adsorption chromatography and HPSEC has been very useful for quantitative evaluation of the main groups of new polar glyceridic compounds, i.e., triglyceride polymers (TGP), triglyceride dimers (TGD), oxidized triglyceride monomers (oxTGM) and diglycerides (DG) (Dobarganes et al., 1988a).

These methodologies can be applied directly to fats and therefore the analytical information obtained refers to compounds maintaining the glyceridic structure. Also, it is possible to apply similar methodologies to the fatty acid methyl esters (FAME) obtained after transesterification, so as to quantitate polar or altered fatty acids globally by silica column chromatography (Dobarganes et al., 1984; Perrin et al., 1985), polymeric fatty acids by HPSEC (Christopoulou and Perkins, 1989) or the main groups of altered fatty acids by combination of silica column and HPSEC (Márquez-Ruiz et al., 1990). Finally, through quantitation of fatty acids by gas-liquid chromatography 
(GLC), the total amount of polar or altered fatty acids can be indirectly attained (Waltking et al., 1975; Dobarganes et al., 1988b).

On the other hand, with respect to the fats and oils used for frying, oils from new seed varieties with modified fatty acid composition are widely used at present. In general, oils from genetically modified seeds differ from the conventional oils in the triglyceride profile whereas they keep similar content and composition of unsaponifiable matter (Purdy, $1985 ; 1986)$. This main difference allows the study of the influence of fatty acid composition without the interference of minor compounds which may have an effect on oil degradation (Boskou, 1988).

The objective of this work was to study the relationships between polar glycerides and polar fatty acids formed in sunflower oils of different fatty acid compositions, heated under well-controlled conditions. Special attention has been paid to the quantitation of nonaltered fatty acids to deduce their implication in the formation of new compounds.

\section{EXPERIMENTAL}

\subsection{Oil Samples and Treatments}

Conventional sunflower oil (SO), high oleic sunflower oil (HOSO) and a $50 \%$ mixture of SO and HOSO (SO/HOSO), both without and with $2 \mathrm{mg} / \mathrm{kg}$ of dimethylpolysiloxane (DMPS) added, were heated at $170^{\circ} \mathrm{C}$ for 10 hours either in oven or plates. Surface-tooil volume ratio was $1 \mathrm{~cm}^{-1}$. Initial and treated samples were stored at $-25^{\circ} \mathrm{C}$ until analyses. Chemical characteristics of the initial oils has been previously reported (Jorge et al., 1996a).

\subsection{Analytical Procedures}

\section{Quantitation and distribution of polar compounds}

Total polar compounds were determined in oil samples by silica column chromatography, following the method proposed by the IUPAC (IUPAC, 1987), with two slight modifications (Dobarganes et al., 1988a). Distribution of polar compounds was performed by HPSEC in a Konik $500 \mathrm{~A}$ chromatograph with a $10 \mu \mathrm{L}$ sample loop. A refractive index detector and two 100 and $500 \AA$ Ultrastyragel columns connected in series operated at $35^{\circ} \mathrm{C}$. The columns were $25 \mathrm{~cm} \times 0.77 \mathrm{~cm}$ inner diameter, packed with a porous, highly cross-linked styrenedivinylbenzene copolymer (< $10 \mu \mathrm{m})$. High-performance liquid chromatography grade tetrahydrofuran served as the mobile phase with a flow of $1 \mathrm{~mL} / \mathrm{min}$, and the sample concentration was between 15 and $20 \mathrm{mg} / \mathrm{mL}$ in tetrahydrofuran (Dobarganes et al., 1988a).

\section{Quantitation and distribution of polar fatty acids}

Fatty acid methyl esters (FAME) were obtained by transesterification of oil samples with sodium methoxide and sulphuric acid-methanol and subsequent recovery of methyl esters (Dobarganes et al., 1984). Methyl esters were separated by silica column chromatography, using hexane/diethyl ether (88:12) to elute a nonpolar fraction and diethyl ether and methanol to obtain the polar fraction. Analyses of the nonpolar and polar fractions were performed by HPSEC, using the chromatographic conditions described above. Quantitation of nonpolar fatty acid dimers (NPFAD) and nonaltered monomers was based on the gravimetric determination of the nonpolar fraction. Oxidized fatty acid monomers (OxFAM), oxidized fatty acid dimers (OxFAD) and fatty acid polymers (FAP) were likewise quantitated in the polar fraction. The methodology was described in detail, including calibration and reproducibility data, in an earlier publication (MárquezRuiz et al., 1990).

\section{Quantitation of non-altered fatty acids}

Fatty acid composition was determined following transesterification of samples with sodium methoxide and sulphuric acid-methanol (AENOR, 1991). FAME were analyzed by gas-liquid chromatography in a SP2380 fused-silica capillary column, $30 \mathrm{~m}$ long and 0.25 $\mathrm{mm}$ i.d., at a temperature of $180^{\circ} \mathrm{C}$.

From fatty acid composition, which provides the percentage of each fatty acid $\left(C_{X}\right)$ on total nonaltered fatty acids (wt \% on FAME), quantitative data of each nonaltered fatty acid (wt \% on oil) can be obtained considering the percentage of total nonaltered fatty acids (100-wt \% of polar fatty acids) as follows:

(wt $\%$ of $C_{x}$ on FAME) $x(100-w t \%$ Polar Fatty Acids) wt $\%$ of $C_{x}$ on oil $=\frac{(w t \% \text { of }}{100}$

\section{RESULTS AND DISCUSSION}

Tables I and II show values for total polar compounds and their distribution in the main groups of alteration compounds for the samples used in the present work. Selection of treatment conditions were directed to obtain alteration levels compatible with the objectives of this study. Thus, samples presented the following characteristics:

1.- For each oil, there were three different alteration levels. For samples heated in plates, the enormeous influence of DMPS addition (Jorge et al., 1996 a; 1996 b) enabled to obtain oils with low and high degradation, as can be observed in Table II, while samples heated in oven had intermediate and much closer levels of polar compounds, as shown in Table I. 
2.- Under the conditions applied, values of polar compounds were high enough to obtain good results in the quantitation of polar fatty acids. After transesterification of the samples, the amount of polar fatty acid methyl esters was much lower than that of polar compounds, mainly constituted by polar glycerides. Given that quantitation is based on a gravimetric determination, the higher the amounts of polar fatty acids the higher the precision (MárquezRuiz et al., 1990).

3.- Values obtained here for polar compounds can be normally found in used frying oils. As it has been reported, the percentage of polar compounds in samples supplied by Food Inspection Services can reach values higher than 50\% (Gertz, 1986; Sebedio, 1987; Dobarganes, 1995) even if degradation is limited at around $25 \%$ (Firestone, 1993).

Table I

Polar compounds (wt\% on oil) and distribution of polar compounds ( $\mathrm{mg} / \mathrm{g}$ oil) in sunflower oils heated in oven at $170^{\circ} \mathrm{C}$ for 10 hours

\begin{tabular}{|c|c|c|c|c|c|c|}
\hline \multirow[b]{2}{*}{ Samples } & \multirow{2}{*}{$\begin{array}{c}\text { Polar } \\
\text { compounds }\end{array}$} & \multicolumn{4}{|c|}{ Distribution } & \multirow[b]{2}{*}{ FA } \\
\hline & & TGP & TGD & oxTGM & DG & \\
\hline so & $\begin{array}{c}46.4 \\
(100)\end{array}$ & $\begin{array}{c}148.5 \\
(32.0)^{\star}\end{array}$ & $\begin{array}{l}161.0 \\
(34.7)\end{array}$ & $\begin{array}{l}140.0 \\
(30.1)\end{array}$ & $\begin{array}{l}10.3 \\
(2.2)\end{array}$ & $\begin{array}{c}4.2 \\
(0.9)\end{array}$ \\
\hline SODMPS & $\begin{array}{l}49.5 \\
(100)\end{array}$ & $\begin{array}{l}166.3 \\
(33.6)\end{array}$ & $\begin{array}{l}164.8 \\
(33.3)\end{array}$ & $\begin{array}{l}148.6 \\
(30.0)\end{array}$ & $\begin{array}{l}10.8 \\
(2.2)\end{array}$ & $\begin{array}{c}4.5 \\
(0.9)\end{array}$ \\
\hline SO/HOSO & $\begin{array}{c}30.8 \\
(100)\end{array}$ & $\begin{array}{c}76.1 \\
(24.7)\end{array}$ & $\begin{array}{l}127.8 \\
(41.5)\end{array}$ & $\begin{array}{l}86.1 \\
(28.0)\end{array}$ & $\begin{array}{l}11.2 \\
(3.6)\end{array}$ & $\begin{array}{c}6.8 \\
(2.2)\end{array}$ \\
\hline SO/HOSO DMPS & $\begin{array}{c}42.2 \\
(100)\end{array}$ & $\begin{array}{l}122.4 \\
(29.0)\end{array}$ & $\begin{array}{l}140.1 \\
(33.2)\end{array}$ & $\begin{array}{l}143.1 \\
(33.9)\end{array}$ & $\begin{array}{l}12.2 \\
(2.9)\end{array}$ & $\begin{array}{c}4.2 \\
(1.0)\end{array}$ \\
\hline HOSO & $\begin{array}{l}24.0 \\
(100)\end{array}$ & $\begin{array}{c}45.1 \\
(18.8)\end{array}$ & $\begin{array}{c}88.1 \\
(36.7)\end{array}$ & $\begin{array}{c}88.1 \\
(36.7)\end{array}$ & $\begin{array}{l}13.7 \\
(5.7)\end{array}$ & $\begin{array}{l}5.0 \\
(2.1)\end{array}$ \\
\hline HOSO DMPS & $\begin{array}{l}25.2 \\
(100)\end{array}$ & $\begin{array}{c}45.9 \\
(18.2)\end{array}$ & $\begin{array}{c}89.2 \\
(35.4)\end{array}$ & $\begin{array}{c}97.2 \\
(38.6)\end{array}$ & $\begin{array}{l}15.4 \\
(6.1)\end{array}$ & $\begin{array}{c}4.3 \\
(1.7)\end{array}$ \\
\hline
\end{tabular}

Abbreviations: SO: sunflower oil; HOSO: high oleic sunflower oil; DMPS; dimethylpolysiloxane. TGP: triglyceride polymers; TGD: triglyceride dimers; oxTGM: oxidized triglyceride monomers; DG; diglycerides; FA: fatty acids + polar unsaponifiable matter.

* Numbers into brackets are percentages on polar compounds.

Table II

Polar compounds (wt\% on oil) and distribution of polar compounds ( $\mathrm{mg} / \mathrm{g}$ oil) in sunflower oils heated in plates at $170^{\circ} \mathrm{C}$ for 10 hours

\begin{tabular}{lcccccc}
\hline \multirow{2}{*}{ Samples } & $\begin{array}{c}\text { Polar } \\
\text { compounds }\end{array}$ & TGP & TGD & oxTGM & DG & FA \\
\cline { 2 - 7 } SO & 59.9 & 246.2 & 179.7 & 158.3 & 10.6 & 4.2 \\
& $(100)$ & $(41.1)^{*}$ & $(30.0)$ & $(26.4)$ & $(1.8)$ & $(0.7)$ \\
SODMPS & 20.2 & 28.3 & 98.6 & 60.2 & 10.3 & 4.6 \\
& $(100)$ & $(14.0)$ & $(48.8)$ & $(29.8)$ & $(5.1)$ & $(2.3)$ \\
SO/HOSO & 55.1 & 208.8 & 137.8 & 189.3 & 11.8 & 3.3 \\
& $(100)$ & $(37.9)$ & $(25.0)$ & $(34.4)$ & $(2.1)$ & $(0.6)$ \\
SO/HOSO DMPS & 19.0 & 28.5 & 86.1 & 58.7 & 12.2 & 4.6 \\
& $(100)$ & $(15.0)$ & $(45.3)$ & $(30.9)$ & $(6.4)$ & $(2.4)$ \\
HOSO & 51.3 & 170.8 & 141.1 & 181.7 & 13.2 & 6.2 \\
& $(100)$ & $(33.3)$ & $(27.5)$ & $(35.4)$ & $(2.6)$ & $(1.2)$ \\
HOSO DMPS & 14.3 & 16.9 & 56.5 & 51.2 & 14.0 & 4.4 \\
& $(100)$ & $(11.8)$ & $(39.5)$ & $(35.8)$ & $(9.8)$ & $(3.1)$ \\
\hline
\end{tabular}

For abbreviations see Table I

* Numbers into brackets are percentages on polar compounds. 
Quantitative results obtained for the main groups of glyceridic compounds indicate the primacy of the formation of polymerization compounds (TGD plus TGP) which contribution to polar compounds was normally higher than $50 \%$ (numbers into brackets in Tables I and II) and even surpassed $70 \%$ for the most altered sample (SO in Table II). These results are in good agreement with those reported for oils with similar levels of polar compounds having been subjected to thermoxidation or frying under very distinct conditions (Arroyo et al., 1992; Cuesta et al., 1993; Dobarganes et al., 1993; Márquez-Ruiz et al., 1995; Pozo-Díaz et al., 1995), thus indicating that the variables of the treatment affect mainly the total degradation level.

Only the unsaturation degree seemed to modulate the distribution of polar compounds. As can be observed in tables I and II, HOSO samples gave higher percentages of oxTGM (between 35.4 and $38.6 \%$ ) than SO samples (between 26.4 and $30.1 \%$ ). This fact denotates, as expected, a lower tendency to polymerization in HOSO samples independently of the total level of polar compounds.

A second step in the evaluation of oils heated at high temperature consisted on the quantitation of fatty acids included in the glycerides that have undergone alteration due to the treatment. Conditions applied during thermoxidation or frying affect primarily unsaturated fatty acids, hence polar compounds evaluated in Tables I and II contained significant amounts of nonaltered fatty acids on account of the structure of glyceridic compounds. Thus, from the three fatty acyls included in polar triglycerides, one or two of them might remain unchanged.

After transesterification of samples, FAME were separated as detailed in the experimental part. Tables III and IV summarize results for total polar fatty acids and for the main groups of compounds in this fraction. As commented above, values of polar fatty acids were much lower than those found for polar compounds or polar glycerides. The last column of Tables III and IV includes the ratio between total polar fatty acids and total polar compounds (see Tables I and II). This value provides a measurement of the average of polar fatty acids in polar glycerides. For instance, a ratio of 0.43 indicates that $43 \%$ of the fatty acids included in polar compounds are polar fatty acids while, consequently, $57 \%$ are nonpolar or nonaltered fatty acids. It is interesting to observe that the ratios were similar for samples heated in oven without and with DMPS added (Table III), whereas they ranged from 0.43 to 0.58 for samples heated in plates (Table IV). For each type of oil, the minimum and maximum ratio corresponded to the lowest and highest level of polar compounds or polar fatty acids, which would indicate the increasing complexity of polar fraction as the oil degradation progresses.

Table III

Polar fatty acids (wt\% on oil) and distribution of polar fatty acids ( $\mathrm{mg} / \mathrm{g}$ oil) in sunflower oils heated in oven at $170{ }^{\circ} \mathrm{C}$ for 10 hours

\begin{tabular}{lcccccc}
\hline & $\begin{array}{c}\text { Polar } \\
\text { Samples }\end{array}$ & \multicolumn{5}{c}{ Distribution } \\
\cline { 2 - 5 } Fatty acids & FAP & oxFAD & NPFAD & oxFAM & PFA/PC* \\
\hline SO & 21.5 & 33 & 64 & 65 & 53 & 0.46 \\
SO DMPS & $(100)$ & $(15.3)^{\star \star}$ & $(29.8)$ & $(30.2)$ & $(24.7)$ & \\
& 22.3 & 32 & 73 & 54 & 64 & 0.45 \\
SO/HOSO & $(100)$ & $(14.4)$ & $(32.7)$ & $(24.2)$ & $(28.7)$ & \\
& 14.5 & 15 & 41 & 48 & 41 & 0.47 \\
SO/HOSO DMPS & $(100)$ & $(10.3)$ & $(28.3)$ & $(33.1)$ & $(28.3)$ & \\
& 18.9 & 30 & 56 & 46 & 57 & 0.45 \\
HOSO & $(100)$ & $(15.9)$ & $(29.6)$ & $(24.3)$ & $(30.2)$ & \\
& 10.2 & 12 & 26 & 28 & 36 & 0.43 \\
HOSO DMPS & $(100)$ & $(11.8)$ & $(25.5)$ & $(27.4)$ & $(35.3)$ & \\
& 11.2 & 13 & 25 & 35 & 39 & 0.44 \\
\hline
\end{tabular}

For abbreviations see Table I; FAP: fatty acid polymers; oxFAD: oxidized fatty acid dimers; NPFAD: non polar fatty acid dimers; oxFAM: oxidized fatty acid monomers + polar unsaponifiable matter.

* Polar fatty acids/Polar compounds

** Numbers into brackets are percentages on polar fatty acids. 
Table IV

Polar fatty acids (wt\% on oil) and distribution of polar fatty acids ( $\mathrm{mg} / \mathrm{g}$ oil) in sunflower oils heated in plates at $170{ }^{\circ} \mathrm{C}$ for 10 hours

\begin{tabular}{|c|c|c|c|c|c|c|}
\hline \multirow[b]{2}{*}{ Samples } & \multirow{2}{*}{$\begin{array}{c}\text { Polar } \\
\text { Fatty acids }\end{array}$} & \multicolumn{4}{|c|}{ Distribution } & \multirow[b]{2}{*}{ PFA/PC* } \\
\hline & & FAP & oxFAD & NPFAD & oxFAM & \\
\hline So & $\begin{array}{c}34.8 \\
(100)\end{array}$ & $\begin{array}{c}60 \\
(17.2)^{\star \star}\end{array}$ & $\begin{array}{c}112 \\
(32.2)\end{array}$ & $\begin{array}{c}69 \\
(19.8)\end{array}$ & $\begin{array}{c}107 \\
(30.8)\end{array}$ & 0.58 \\
\hline SO DMPS & $\begin{array}{c}9.4 \\
(100)\end{array}$ & $\begin{array}{c}8 \\
(8.5)\end{array}$ & $\begin{array}{c}26 \\
(27.7)\end{array}$ & $\begin{array}{c}22 \\
(23.4)\end{array}$ & $\begin{array}{c}38 \\
(40.4)\end{array}$ & 0.47 \\
\hline SO/HOSO & $\begin{array}{l}28.8 \\
(100)\end{array}$ & $\begin{array}{c}37 \\
(12.8)\end{array}$ & $\begin{array}{c}88 \\
(30.6)\end{array}$ & $\begin{array}{c}68 \\
(23.6)\end{array}$ & $\begin{array}{c}95 \\
(33.0)\end{array}$ & 0.52 \\
\hline SO/HOSO DMPS & $\begin{array}{c}9.0 \\
(100)\end{array}$ & $\begin{array}{c}6 \\
(6.7)\end{array}$ & $\begin{array}{c}21 \\
(23.3)\end{array}$ & $\begin{array}{c}17 \\
(18.9)\end{array}$ & $\begin{array}{c}46 \\
(51.1)\end{array}$ & 0.47 \\
\hline HOSO & $\begin{array}{l}25.0 \\
(100)\end{array}$ & $\begin{array}{c}32 \\
(12.8)\end{array}$ & $\begin{array}{c}75 \\
(30.0)\end{array}$ & $\begin{array}{c}58 \\
(23.2)\end{array}$ & $\begin{array}{c}85 \\
(34.0)\end{array}$ & 0.48 \\
\hline HOSO DMPS & $\begin{array}{c}6.2 \\
(100)\end{array}$ & $\begin{array}{c}2 \\
(3.2)\end{array}$ & $\begin{array}{c}14 \\
(22.5)\end{array}$ & $\begin{array}{c}14 \\
(22.6)\end{array}$ & $\begin{array}{c}32 \\
(51.6)\end{array}$ & 0.43 \\
\hline
\end{tabular}

For abbreviations see Table I and III

* Polar fatty acids/Polar compounds

${ }^{\star \star}$ Numbers into brackets are percentages on polar fatty acids.

Good statistical figures were found for regression of polar fatty acids on polar compounds. Figure 1 shows graphically the linear equation obtained for this set of data $(n=12)$. The regression coefficient was 0.981 ( $P<0.001)$ and the standard errors for regression, intercept and slope were 1.84, 1.37 and
0.03 , respectively. It is interesting to note that an excellent correlation was found although oils with very different unsaturation level were considered. This would suggest that it is possible to make predictions from polar compounds to polar fatty acids regardless of the type of oil used.

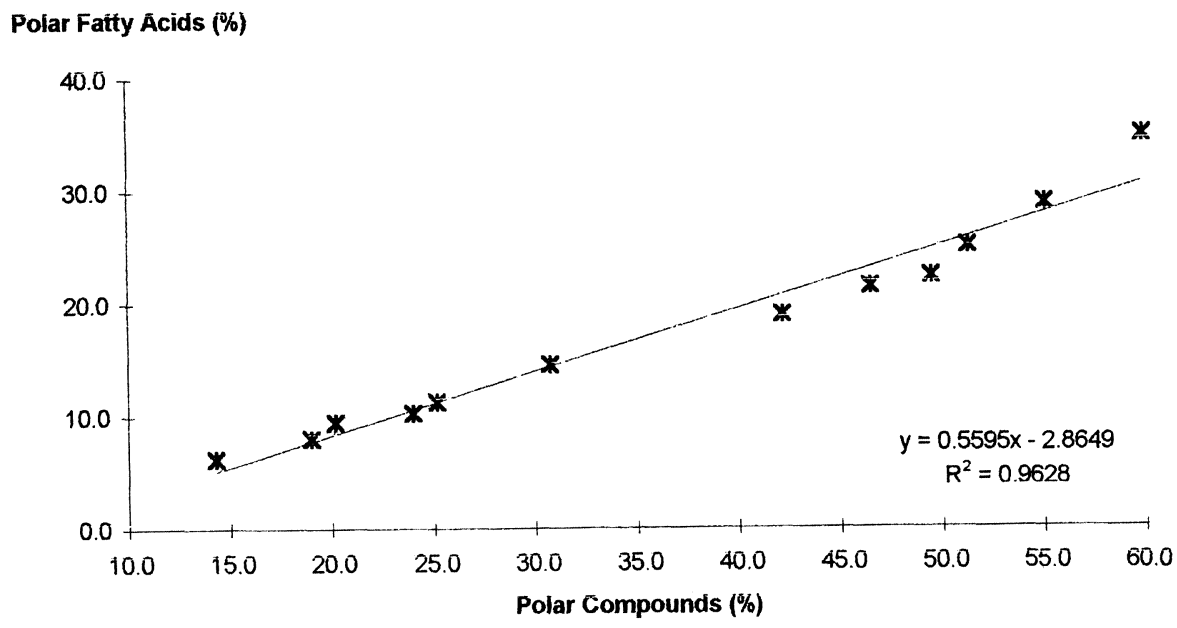

Figure 1

Regression of polar fatty acids on polar compounds. 
With respect to polar fatty acid distribution, the profile seemed to be similar to that found for polar glycerides, the high proportion of polymerization compounds (PFA + NPFAD + oxFAD), increasing with oil degradation, standing out. Nevertheless, it is important to remark two differences between polar fatty acids and polar glycerides. On one hand, the low amounts found for FAP as compared to those of TGP in Table I and II and, on the other, the great amounts of dimeric fatty acids (NPFAD + oxFAD) reached in the most altered sample (SO in Table IV), even as high as that found for TGD (Table II). Both facts clearly indicate the high contribution of dimeric fatty acid linkages in the formation of polymeric triglycerides.

Even though the methodologies applied are of great use to gain insight on the degradation of fats at high temperature, a more detailed quantitation of the alteration compounds has not been possible so far due to the high number of individual compounds formed. However, a simple further step to increase knowledge on fat degradation at high temperature consists on the evaluation of the main fatty acids involved in the formation of polar fatty acids, which can not be deduced from the analysis of the different groups of polar fatty acids. Towards this aim, data of fatty acid compositions as determined by GLC (wt \% on FAME) were transformed into quantitative data (wt $\%$ on oil), as described in the experimental part. Results are presented in Table V. As can be observed, saturated fatty acids did not undergo any appreciable degradation as they remained practically at the initial concentrations in all the samples. Only linoleic and oleic acids decreased in treated samples, although to a different extent. From these data, the loss of the main fatty acids after the heating treatment can be easily deduced by direct comparison of the treated samples and initial oils.

Table VI shows the losses of oleic and linoleic acids which are the only fatty acids undergoing significant degradation. In the last column, the ratio between losses of linoleic and oleic acid has been also included. Results demonstrated that participation of such fatty acids in polar fatty acid formation depended on both the oil alteration and the relative concentration of oleic and linoleic acids. On one hand, the ratio between both unsaturated acids decreased as the amount of polar fatty acids increased, independently of the type of oil, indicating higher contribution of oleic acid as the concentration of linoleic decreased. On the other, the higher the concentration of linoleic acid, the higher the ratio at any level of polar fatty acids.

It is interesting to note the values obtained for HOSO heated in plates, where the loss of oleic acid $(14.6 \%)$ was higher than that corresponding to linoleic acid (10.2\%). Considering that concentration of linoleic acid was still $7.7 \%$ in this sample, this finding would support that oleic acid can be easily altered since the beginning of the heating in monounsaturated or partially hydrogenated oils with low content of linoleic acid.

Table V

Major fatty acids (wt \% on oil) in sunflower oils heated at $170{ }^{\circ} \mathrm{C}$

\begin{tabular}{|c|c|c|c|c|c|}
\hline Samples & $\mathrm{C}_{16: 0}$ & $C_{18: 0}$ & $C_{18: 1}$ & $\mathrm{C}_{18: 2}$ & $\begin{array}{c}\text { Non altered } \\
\text { fatty acids }\end{array}$ \\
\hline \multicolumn{6}{|l|}{ INITIAL OILS } \\
\hline so & 6.2 & 4.7 & 20.3 & 66.7 & 100 \\
\hline SO/HOSO & 5.3 & 4.5 & 46.8 & 41.2 & 100 \\
\hline HOSO & 4.0 & 4.3 & 71.8 & 17.9 & 100 \\
\hline \multicolumn{6}{|l|}{ HEATED IN OVEN } \\
\hline SO & 6.4 & 4.9 & 18.2 & 47.3 & 78.6 \\
\hline SODMPS & 5.9 & 4.6 & 18.5 & 46.5 & 77.7 \\
\hline SO/HOSO & 5.2 & 4.5 & 45.0 & 28.4 & 85.5 \\
\hline SO/HOSO DMPS & 5.1 & 4.8 & 44.3 & 24.5 & 81.1 \\
\hline HOSO & 3.9 & 4.0 & 68.6 & 11.0 & 89.8 \\
\hline HOSO DMPS & 4.2 & 4.1 & 68.2 & 10.3 & 88.8 \\
\hline \multicolumn{6}{|l|}{ HEATED IN PLATES } \\
\hline SO & 6.2 & 4.5 & 17.3 & 35.3 & 65.2 \\
\hline SODMPS & 6.0 & 4.7 & 20.1 & 57.7 & 90.6 \\
\hline $\mathrm{SO} / \mathrm{HOSO}$ & 5.3 & 4.3 & 43.0 & 16.9 & 71.2 \\
\hline SO/HOSO DMPS & 5.1 & 4.6 & 46.2 & 33.7 & 91.0 \\
\hline HOSO & 4.3 & 4.5 & 57.2 & 7.7 & 75.0 \\
\hline HOSO DMPS & 4.0 & 4.0 & 70.6 & 13.5 & 93.8 \\
\hline
\end{tabular}

For abbreviations see Table I 
Table VI

Losses of unsaturated fatty acids (wt\% on oil) in sunflower oils heated at $170{ }^{\circ} \mathrm{C}$

\begin{tabular}{lccc}
\hline Samples & $\mathbf{C}_{\mathbf{1 8 : 1}}$ loss & $\mathbf{C}_{\mathbf{1 8 : 2}}$ loss & $\mathbf{C}_{\mathbf{1 8 : 2}}$ loss $\mathbf{C}_{\mathbf{1 8 : 1}}$ loss \\
\hline HEATED IN OVEN & & & \\
SO & 2.1 & 19.4 & 9.2 \\
SO DMPS & 1.8 & 20.2 & 11.2 \\
SO/HOSO & 1.8 & 12.8 & 7.1 \\
SO/HOSO DMPS & 2.5 & 16.7 & 6.7 \\
HOSO & 3.2 & 6.9 & 2.2 \\
HOSO DMPS & 3.6 & 7.6 & 2.1 \\
HEATED IN PLATES & & & \\
SO & 3.0 & 31.4 & 10.5 \\
SO DMPS & 0.2 & 9.0 & 45.0 \\
SO/HOSO & 3.8 & 24.3 & 6.4 \\
SO/HOSO DMPS & 0.6 & 7.5 & 12.5 \\
HOSO & 14.6 & 10.2 & 0.7 \\
HOSO DMPS & 1.2 & 4.4 & 3.7 \\
\hline
\end{tabular}

For abbreviations see Table I

Finally, the results from this study -good correlation between polar glycerides and polar fatty acids, and evaluation of the fatty acids involved in formation of polar fatty acids- indicate that through a simple quantitative analysis of fatty acids in heated samples i.e., by adding methyl heptadecanoate as internal standard, total concentration of polar fatty acids could be attained and polar compounds could be predicted. This possible approach is being checked on a high number of samples with the objective of proposing a simpler and rapid method alternative to polar compound determination. It would be particularly useful in those laboratories or industries where a high number of used frying oils are routinely analyzed to check whether the limit for oil rejection has been overpassed or not.

\section{ACKNOWLEDGEMENT}

This study was supported by an EU grant (AIR1 CT92-0687) and by CICYT (ALI 95-0736). The authors thank Mercedes Giménez for assistance. Neuza Jorge was supported by a fellowship from $\mathrm{CNP}_{\mathrm{q}}$ (Brasil).

\section{BIBLIOGRAPHY}

Asociación Española de Normalización (AENOR). Norma UNE 55 037-73, Catálogo de Normas UNE de 1991. Madrid, 1991.

Arroyo, R., Cuesta, C., Garrido-Polonio, C., López-Varela, S. and Sánchez-Muniz, F.J. (1992). -«High-performance size- exclusion chromatographic studies on polar components formed in sunflower oil used for frying".- J. Am. Oil Chem. Soc. $69,557-563$

Boskou, D. (1988). - «Stability of frying oils» in Frying of Food. Principles, Changes, New Approaches. Ed. by G. Varela, A.E. Bender and I.D. Morton. VCH, Chichester (England) p 174182.

Christopoulou, C.N. and Perkins, E.G. (1989). -«lsolation and characterization of dimers formed in used soybean oil».- J. Am. Oil Chem Soc. 66, 1360-1370.

Cuesta, C., Sánchez-Muniz, F.J., Garrido-Polonio, C., LópezVarela, S. and Arroyo, R. (1993). - «Thermoxidative and hydrolytic changes in sunflower oil used in fryings with a fast turnover of fresh oil».- J. Am. Oil Chem Soc. 70, 1069-1073.

Dobarganes, M.C., Pérez-Camino, M.C. y Gutiérrez GonzálezQuijano, R. (1984). - Métodos analíticos de aplicación en grasas calentadas. I. Determinación de ésteres metílicos no alterados".- Grasas y Aceites 36, 172-177.

Dobarganes, M.C., Pérez-Camino, M.C. and Márquez-Ruiz, G. (1988a). - - High-performance size-exclusion chromatography of polar compounds in heated and nonheated fats».- Fat. Sci. Technol. 90, 308-311.

Dobarganes, M.C. and Pérez-Camino, M.C. (1988b). - «Fatty acid composition: a useful tool for the determination of alteration level in heated fats».- Rev. Fr. Corps Gras 35, 67-70.

Dobarganes, M.C., Márquez-Ruíz, G. and Pérez-Camino, M.C. (1993). - «Thermal stability and frying performance of genetically modified sunflower seed oils".- J. Agric. Food Chem. 41, 678-681.

Dobarganes, M.C. y Márquez-Ruiz, G. (1995). - «Calidad de las grasas de fritura en el sector de restauración de Andalucia».- Grasas y Aceites 46, 115-120.

Firestone, D. (1993). - «Worldwide regulation of frying fats and oils».- Inform 4, 1366-1371.

Gertz, Ch. (1986). - «Chromatographische Methoden bei der Untersuchung von Fritierfetten". - Fette Seifen Anstrichm. 88, 475-480.

Jorge, N., Márquez-Ruiz, G., Martín-Polvillo, M., Ruiz-Méndez, M.V. and Dobarganes, M.C. (1996a). - «Influence of dimethylpolisiloxane addition to edible oils: dependence on the main variables of the frying process".- Grasas y Aceites 47, 14-19. 
Jorge, N., Márquez-Ruiz, G., Martín-Polvillo, M., Ruiz-Méndez, M.V. and Dobarganes, M.C. (1996b). - «Influence of the addition of dimethylpolysiloxane addition to frying oils: Peformance of sunflower oils in discontinuous and continuous laboratory frying".- Grasas y Aceites 47, 20-25.

Márquez-Ruiz, G., Pérez-Camino, M.C. and Dobarganes, M.C. (1990). - «Combination of adsorption and size-exclusion chromatography for the determination of fatty acid monomers, dimers and polymers".- J. Chrom. 514, 37-44.

Márquez-Ruiz, G., Tasioula-Margari, M. and Dobarganes, M.C. (1995).-«Quantitation and distribution of altered fatty acids in frying fats".- J. Am. Oil Chem Soc. 72, 1171-1176.

Perrin, J.L., Redero, F. and Prevot, A. (1984). -«Dosage rapide des polymères de triglycérides par chromatographie d'exclusion".- Rev. Fr. Corps Gras 31, 131-134.

Perrin, J.L., Perfetti, P., Dimitriades, C. et Naudet, M. (1985). - Etude analytique approfondie d'huiles chauffées. I. Techniques analytiques et essais préliminaires».- J. Agric. Food Chem. 32, 151-158.

Pozo Díez, R.M. Masoud Musa, T.A., Pérez-Camino, M.C. y Dobarganes, M.C. (1995). - «Intercambio lipídico durante la fritura de patatas prefritas congeladas en aceite de girasol alto oleico".- Grasas y Aceites 46, 85-91.

Purdy, H. (1985). - «Oxidative stability of high oleic sunflower and safflower oils».- J. Am. Oil Chem Soc. 62, 523-525.

Purdy, H. (1986). - «High oleic sunflower: physical and chemical characteristics".- J. Am. Oil Chem Soc. 63, 1062-1066.

Sebedio, J.L., Grandgirard, A., Septier, Ch. and Prevost, J. (1987). - «Etat d'altération de quelques huiles de friture prélevées en restauration".- Rev. Corps Gras 34, 15-18.

Waltking, A.E., Seery, W.E. and Bleffert, G.W. (1975). - CChemical analysis of polymerization products in abused fats and oils".- J. Am. Oil Chem Soc. 52, 96-100.

Waltking, A.E. and Wessels, H. (1981). - «Chromatographic separation of polar and nonpolar components of frying fats».- J. Assoc. Off. Anal. Chem. 64, 1329-1330.

Wolf, J.P., Mordret, F.X. and Dieffenbacher, A. (1991). - «Determination of polymerized triglycerides in oils and fats by high performance liquid chromatography».- Pure and Appl. Chem. 63, 1163-1171.

Recibido: Septiembre 1996 Aceptado: Enero 1997 